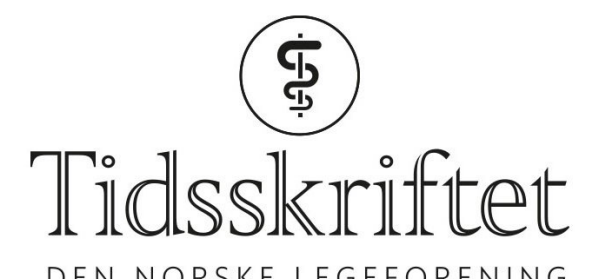

DEN NORSKE LEGEFORENING

\title{
Til lags åt alle kan ingen gjera ...
}

TIDLIGERE I TIDSSKRIFTET

TONE BERGSET

E-post: tone.bergset@legeforeningen.no

Ganske nylig ble Tidsskrift for Den norske legeforening kåret til Årets tidsskrift 2018 av Norsk tidsskriftforening. I juryens begrunnelse kunne vi bl.a. lese at Tidsskriftet kanskje er den fremste eksponenten blant fagtidsskrifter for å vedlikeholde og videreutvikle en fagterminologi på norsk. Vi jobber daglig med denne viktige oppgaven, men litt motbør møter man jo innimellom, som seg hør og bør. Så også i 1929, da Tidsskriftet gikk over til en ny, offisiell rettskrivning (Tidsskr Nor Lægeforen 1929; 49: 243-45).

\section{Fagartikler, medisinsk administrasjon, kollegiale spørsmål m.v.}

\section{"TIDSSKRIFTET»S SPROG.}

Den i «Tidsskriftet»s første nummer for i år bebudede forandring i «Tidsskriftets»s sprog er nu kommet $i$ andet hefte. - Da jeg skulde til med dette nummer, husket jeg ikke på dette glædelige budskap - og begynte trøstig på første artikel. Men det var ikke mange linjer jeg var kommet, før den nye sprogdrakt virket således på mig, at artiklens faglige indhold blev mig aldeles fordærvet, jeg måtte simpelt hen - for denne gang ialfald - gi op. Istedenfor gav jeg mig - nolens volens - til blot at se igjennem artiklen fra dens orthografiske side - NB. Ikke dens sproglige. For det er vel ikke sprogets, men den såk. retskrivnings forandring redaktionens glade budskap går ut på - altså for så vidt et galt valgt uttryk for meddelelsen heldigvis! Det skulde bare manglet at det virkelig var sproget: Nu går vi over til landsmål! Forresten, man vet sig jo aldrig tryg for hvad man kan risikere - men den dag melder ialfald jeg mig ut av Lægeforeningens resp. «Tidsskriftet» - hvis jeg da ikke forinden er død. 


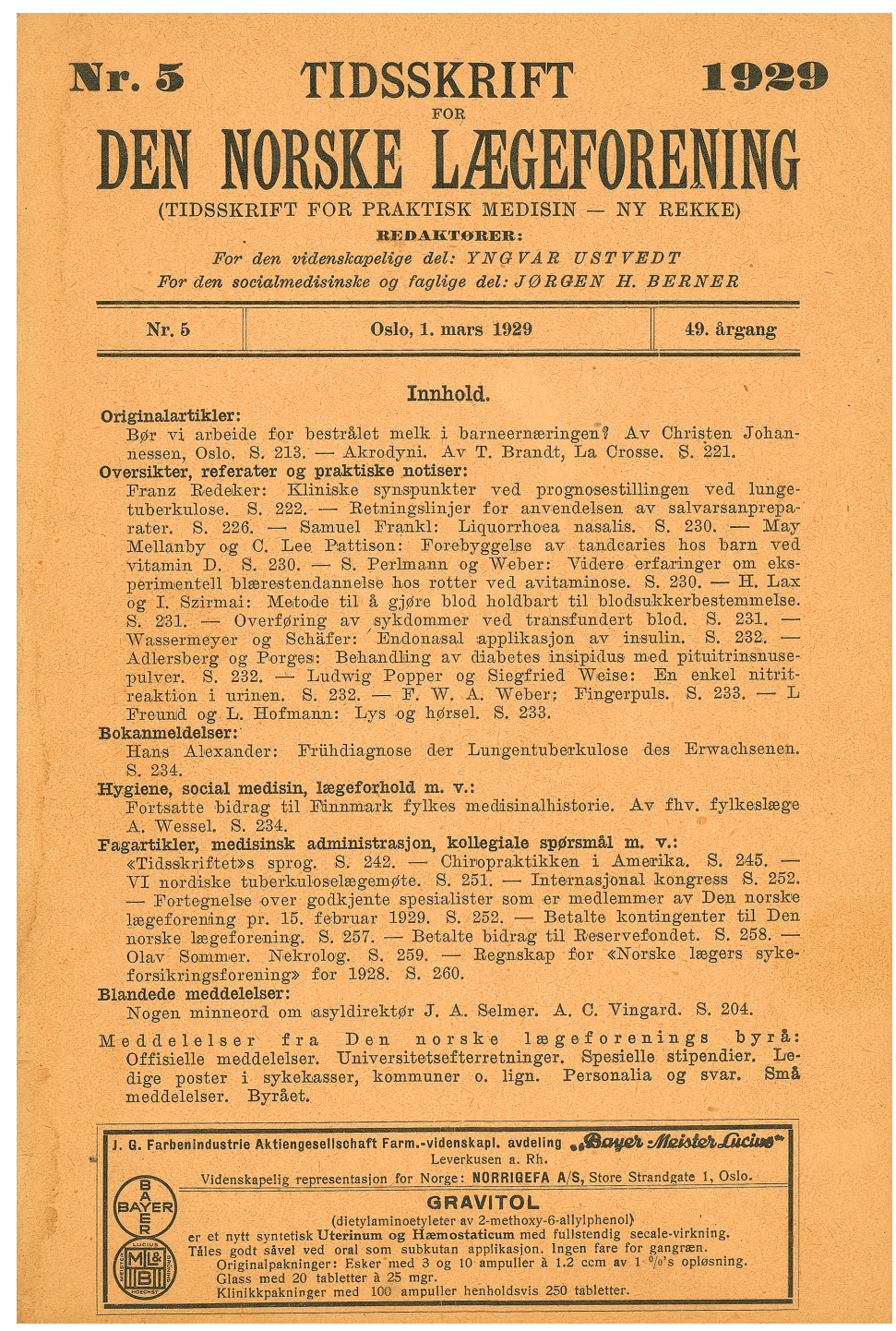

Men det er sandelig galt nok som det tegner; jeg har set på første artikkel, mere orket jeg ikke. Thi hvad er det ikke for et sammensurium av «retskrivning» allerede denne ene artikel byr på? dels i behandlingen av de rent medisinske ord, dels i de almindelige allemandsord d. v. s. den såk. officielle retskrivningen av 1917 eller hvad den nu heter. Det sidste er en side av saken for sig - dens logiske umuligheter er jo kjendt vare fra før, hvor den har făt smuglet sig ind; jeg skal ikke større fæste mig ved den - men leilighetsvis kan man jo ikke undgå at bli hængende fast i de værste uhyrligheter.

(...)

Nei det er en frygtelig sørpe altsammen, kjære redaktion - og for den medicinske stand ikke minst et bedrøvelig tidsdekadencens tegn. Av medicineren forlangtes før sprogkundskap og sprogfølelse - og det var vel.

Sarpsborg i januar 1929.

G. Winge

Da «Tidsskriftet» fra 1. januar iår gikk over til den offisielle rettskrivning, var redaksjonen naturligvis forberedt på at det kunde vekke misnøie på enkelte hold. Imidlertid er «reformen» inntil nu kollega Winge optrer, blitt møtt med velvilje, ja en eldre kollega skriver til mig, at det "gleder ham opriktig».

Bestemmende for redaksjonen, når den nu fulgte eksemplet fra andre tidsskrifter, var for det første at det volder besvær for trykkeriet, hvor typografen snart skal sette en artikkel efter den gamle og snart efter den nye rettskrivning. Men den viktigste grunn er, at når man nu først h a r en offisiell rettskrivning, så bør den følges uansett om man personlig liker den eller ikke i et offisielt tidsskrift. 
$(\ldots)$

Red.

Publisert: 12. juni 2018. Tidsskr Nor Legeforen. DOI: 10.4045/tidsskr.18.0366

(C) Tidsskrift for Den norske legeforening 2020. Lastet ned fra tidsskriftet.no 